\title{
STRATEGI BERTAHAN MASYARAKAT DENPASAR PADA MASA PANDEMI COVID- 19 (STUDI PADA PENERIMA PROGRAM STIMULUS PIP2)
}

\author{
I Ketut Sida Arsa1, Ni Made Ary Widiastini², Fajar Yualida Isti Koma ${ }^{3}$ \\ 1)Fakultas Seni Rupa dan Desain, Institut Seni Indonesia, Jl.Nusa Indah Denpasar, 80235, \\ Indonesia \\ 2)Fakultas Ekonomi, Universitas Pendidikan Ganesha, Jl. Udayana No. 11 Singaraja, 81116, \\ Indonesia \\ 3)Magister Terapan Perencanaan Pariwisata, Politeknik Negeri Bali, Kampus Bukit Jimbaran, \\ Kec. Kuta Selatan, Kabupaten Badung, Bali 80364, Indonesia \\ email: ary.widiastini@gmail.com
}

\begin{abstract}
ABSTRAK
Pandemi berdampak pada terpuruknya ekonomi masyarakat di Bali, khususnya di Denpasar yang merupakan ibu kota provinsi. Berbagai cara ditempuh pemerintah untuk membantu masyarakat bertahan di masa sulit. Penelitian ini bertujuan untuk menganalisis dan mendeskripsikan strategi resiliensi masyarakat Kota Denpasar pada masa pandemi covid-19 dengan mengamati masyarakat penerima program stimulus PIP2 (Pandemic Incubation Program), yang merupakan kelanjutan program inkubasi tahun sebelumnya. Pengumpulan data penelitian menggunakan metode kuesioner (Google Form), wawancara dengan responden (baik langsung maupun tidak langsung/online), dan dokumentasi. Data dianalisis secara deskriptif kualitatif dengan menggunakan pendekatan kajian budaya. Dalam penelitian ini ditemukan bahwa program stimulus yang diberikan oleh Pemerintah Kota Denpasar disambut baik oleh masyarakat yang memiliki KTP Denpasar dengan mengajukan proposal pengajuan dana dengan menunjukkan usaha yang sedang dikembangkan. Modal berupa uang tunai yang diterima dapat digunakan untuk mengembangkan usahanya walaupun hanya sedikit peserta yang mampu bertahan hingga program berakhir. Selain tetap melakukan inovasi produk melalui diskusi langsung atau WhatsApp dengan inkubator bisnis sebagai pendampingnya, peserta yang menerima program stimulus PIP2 juga memanfaatkan media sosial untuk menjual produk.
\end{abstract}

Kata Kunci: Bertahan, Denpasar, Masyarakat, Program, Stimulus, Strategi

\section{ABSTRACT}

The pandemic has an impact on the economic decline of the people in Bali, especially in Denpasar, which is the provincial capital. The government has taken various ways to help people survive in difficult times. This study aims to analyze and 
describe the resilience strategy of the Denpasar City community during the COVID-19 pandemic by observing the recipients of the PIP2 (Pandemic Incubation Program) stimulus program. Collecting research data using a questionnaire method (Google Form), interviews with respondents (either directly or indirectly/WhatsApp), and documentation. The data were analyzed descriptively qualitatively using a cultural studies approach. In this study, it was found that the stimulus program provided by the Denpasar City Government was welcomed by people who had a Denpasar ID card by submitting a proposal for submitting funds by showing the business being developed. Capital in the form of cash received can be used to expand their business even though only a few participants are able to survive until the program ends. In addition to continuing to innovate products through direct or by WhatsApp discussions with a business incubator as a companion, participants who received the PIP2 stimulus program also used social media to sell products.

Keywords: Community, Denpasar, Program, Resilience, Stimulus, Strategy

\section{PENDAHULUAN}

Kondisi ekonomi hingga saat ini belum pulih, masa pandemi yang telah berjalan setahun, telah memberikan dampak tidak baik terhadap berbagai sektor ekonomi (Peter, 2020), dan secara khusus pada sektor formal (Muslim, 2020). Selain dikarenakan penyebaran virus yang telah merenggut banyak korban, sehingga seluruh masyarakat wajib berhati hati dalam beraktivitas, pemberlakuan berbagai pembatasan pergerakan manusia antar wilayah berdampak pada kegiatan ekonomi. Bali yang telah bergantung dari sektor pariwisata pun mengalami kondisi semakin terpuruk. Pembatasan pergerakan manusia antar negara yang diberlakukan secara nasional dan internasional, secara langsung berdampak pada penurunan jumlah kunjungan wisatawan, yang menyebabkan industri pariwisata, khususnya di Bali mengalami kolaps. Tingkat hunian hotel di bawah 30\%, membuat hotel sulit mengoperasionalkan hotelnya, sehingga memilih untuk tutup, hingga menerapkan pemutusan hubungan kerja karyawan.

Ketidakmampuan menghasilkan pendapatan sebagai akibat kondisi ekonomi yang buruk berdampak pada kehidupan keluarga masyarakat Bali, khususnya Denpasar yang banyak masyarakatnya bekerja di sektor pariwisata. Dalam hal ini, keluarga sebagai sebuah sistem sosial, membutuhkan pemasukan untuk bisa bertahan hidup. Bekerja memiliki tujuan fsinauntuk mendapatkan uang yang digunakan memenuhi kebutuhan hidup. Pemenuhan kebutuhan keluarga tidak bisa diabaikan, dalam hal kini keluarga berfungsi untuk memenuhi aneka kebutuhan manusia, yakni kebutuhan fisikal, psikologis, sosial, kultural, dan spiritual (Lestari, 2012). Pemenuhan kebutuhan keluarga mengharuskan manusia untuk bekerja mengingat bahwa melalui kerja manusia mengaktualisasikan dirinya sebagai manusia sekaligus mendapatkan uang untuk membeli berbagai kebutuhan hidup.

Melihat kondisi buruk tersebut, pemerintah kota Denpasar 
mengambil kebijakan untuk memberikan bantuan uang bagi masyarakat yang berdomisi Denpasar. Namun, untuk menghindari terjadinya sistem bagi uang yang manfaatnya kurang dapat dirasakan dalam waktu lama, pemerintah kota Denpasar menyalurkan sejumlah uang melalui program bantuan stimulus bagi masyarakat yang memiliki usaha. Program tersebut bernama PIP (Pandemic Incubation Program), yang merupakan program bantuan stimulus bagi masyarakat berdomisili Denpasar yang memiliki usaha untuk mendapatkan bantuan uang tunai dan pendampingan dari unit inkubator bisnis yang ada di Bali. Tujuan penelitian ini untuk menganalisis dan mendeskripsikan strategi resiliensi masyarakat Kota Denpasar pada masa pandemi covid-19 dengan mengamati masyarakat penerima program stimulus PIP2, yang merupakan program lanjutan tahun sebelumnya (tahun 2020). PIP tersebut mulai dilaksanakan pada tahun 2020, dan cukup memberikan hasil yang memuaskan, yakni terdapat $10 \%$ usaha masyarakat mampu tumbuh dan berkembang, meskipun hanya diberikan bantuan sejumlah Rp. 1.000.000,-. Melihat hal tersebut, pada tahun 2021, bantuan dana pada program stimulus tersebut ditambahkan yakni menjadi Rp. 1.500.000,-. Harapannya, terdapat 20\% usaha yang mampu berkembang, sehingga mampu memberikan pendapatan sesuai harapan bagi pemilik usaha, bahkan mampu membuka lapangan kerja, misalnya menjadi reseller produk yang dijual.
Program pemerintah kota Denpasar menarik untuk dicermati, mengingat pada tahun 2020 mampu menunjukkan hasil yang baik. Dalam pelaksanaannya banyak masyarakat yang antusias untuk mendaftarkan diri sebagai penerima bantuan, meskipun jumlah uang tunai yang diberikan tidak banyak. Meskipun bantuan modal tunai yang diberikan jumlahnya tidak besar, namun masyarakat yang memiliki hak untuk sebagai penerima program stimulus PIP2 dengan penuh semangat mengajukan usulan yang mensyaratkan wajib memiliki usaha yang sedang dikembangkan. Hal tersebut menarik dicermati, khususnya strategi bertahan yang mereka lakukan dalam mempertahankan usaha yang dikembangkan dengan modal kecil.

\section{METODE}

Pendataan dilakukan dengan wawancara, kuesioner dan observasi kepada pihak penyelenggara PIP2. Kuesioner diberikan kepada seluruh peserta PIP2 grup 19 yang berjumlah sebanyak lima puluh delapan orang. Untuk observasi dan wawancara dilakukan kepada dua belas orang penerima program bantuan stimulus, yang merupakan mantan pekerja di pariwisata yang terdampak pandemi, baik mengalami pemutusan kerja maupun pemotongan waktu kerja yang berdampak pada pemotongan gaji. Kegiatan penelitian dilakukan bulan Mei hingga Agustus 2021. Dalam hal ini pemilihan informan kunci, mengadopsi gagasan Tremblay (Marshall, 1996), yang menjelaskan karakteristik menjadi kunci informan 
diantaranya (1) Memiliki pemahaman tentang informasi yang dicari dalam penelitian; (2) Bersedia untuk mengkomunikasikan pengetahuan mereka kepada pewawancara; (3) Dapat mengkomunikasikan pengetahuan mereka dengan cara yang dapat dipahami oleh pewawancara; (5) Ketidakberpihakan, informan kunci bersifat objektif. Penelitian ini pendekatan kajian budaya (Barker, 2005) diterapkan untuk melihat praktik sosial penerima program stimulus dalam bertahan dan mempertahankan usahanya di masa pandemi.

\section{HASIL DAN PEMBAHASAN}

\section{Alasan Pemerintah Kodya Denpasar Melaksanakan Pandemic Incubation Program (PIP) Tahap 2 Tahun 2021}

Kondisi perekonomian Bali yang hingga saat ini belum membaik, membuat pemerintah terus berusaha untuk melakukan sesuatu yang mampu membantu masyarakat untuk keluar dari situasi sulit. Bali yang telah menggantungkan sumber pendapatan utamanya dari sektor pariwisata (Suryawan, 2011), mampu memberikan dampak pada sektor lain yang selama ini sebagai pendukung pariwisata tersebut. Begitupula ketika pariwisata Bali mengalami masalah, sektor pendukungnya pun ikut terdampak, seperti usaha kerajinan, fashion, kuliner dan lainnya. Melihat kondisi tersebut, salah satu program yang ditawarkan kepada masyarakat adalah PIP. Program ini dilaksanakan pada tahun 2020 dan dilaksanakan lagi pada tahun 2021, dengan harapan ada usaha yang bertahan maupun bertumbuh dan berkembang.

$$
\text { Implementasinya, PIP yang }
$$

dilaksanakan pada tahun 2020 memberikan bantuan kepada masyarakat yang memenuhi syarat sebanyak 2369 orang. Dalam hal ini, peserta yang berhak mengajukan permohonan dan menerima bantuan harus memiliki KTP Denpasar dan usaha milik pribadi. Selain itu, disyaratkan juga kepada calon penerima harus melakukan registrasi pada sistem yang diberlakukan untuk mendapatkan proses penyaringan. Proses penyaringan tersebut bertujuan agar pemerintah mampu memberikan bantuan tepat sasaran. Seleksi merupakan hal yang penting dilakukan oleh sebuah organisasi, dengan tujuan mendapatkan input yang baik sesuai harapan. Begitupula yang dilakukan oleh pemerintah Kodya Denpasar yang harus melakukan seleksi terhadap 7.715 pendaftar pada program PIP tahun 2021 yang hanya mampu memberikan bantuan kepada 1.680 orang. Dalam prosesnya, tim program melakukan seleksi yang sangat baik untuk mampu menghasilkan keputusan yang tepat dalam memberikan bantuan, terutama di masa pandemi covid-19.

Peserta penerima bantuan stimulus PIP tahun 2021, sebelum dinyatakan lulus sebagai penerima bantuan, mereka wajib mengikuti pelatihan yang dilaksanakan secara online tentang ide usaha, pengembangan produk serta pemasaran produk. Selanjutnya, pemerintah juga memberikan pendampingan bagi peserta yang dinyatakan lulus dengan melibatkan 
peran inkubator yang ada di Bali. Pendampingan dilakukan dengan dua metode baik direktif maupun non direktif (Adi, 2008), menyesuaikan dengan kebutuhan dari masingmasing peserta, yang tentunya membutuhkan kemampuan komunikasi yang baik dalam proses mendampingi. Inkubator bisnis yang dilibatkan adalah Inkubator Bisnis Primakara, Inkubator Universitas Udayana, Bantuan Klinik UKM, Rumah Kemasan Bali, Universitas Mahasaraswati, Inkubator Bisnis Ngurah Rai, Inkubator Bisnis STIKI, Inkubator Bisnis IKIP Saraswati, Inkubator Bisnis ITB Stikom Bali, Inkubator Bisnis UNHI, Inkubator Bisnis Poltekpar, Inkubator Bisnis Tohpati, Inkubator Bisnis Undiknas, Inkubator Bisnis Warmadewa, Inkubator Bisnis Undiksha, Inkubator Bisnis IDB Bali.

\section{Pelaksanaan PIP Tahap 2 Dilaksanakan oleh Pemerintah Kodya Denpasar}

Jenis usaha peserta yang lolos seleksi dalam program PIP tahun 2021 adalah usaha yang dalam lingkup industri kreatif. Industri kreatif (Howkins, 2013) dalam implementasinya dikenal juga dengan istilah industri budaya dan ekonomi kreatif, yang menjadikan kreativitas sebagai hal penting dalam mengembangkan, memasarkan dan mempertahankan eksistensi produk. Kegiatan pendampingan kepada peserta penerima (PIP2) dilaksanakan selama tiga bulan penuh, yang dilakukan baik secara langsung (luring) atau online (daring). Untuk kegiatan pendampingan yang dilaksanakan secara daring dapat dilakukan dengan komunikasi melalui Whatsapp grup atau peserta dipersilakan untuk berdiskusi dengan pendampingnya secara langsung.

Produk yang dijual oleh peserta PIP2 sangat bervarian dan cukup memerhatikan tren yang berkembang di masyarakat. Dalam hal ini gaya hidup masyarakat (Suyanto, 2014) menjadi penting dalam mengembangkan produk termasuk juga cara menjualnya, yang saat ini sudah serba digital. Berdasarkan hasil survei melalui google form, diketahui bahwa sebagian besar peserta yang lulus sebagai penerima hibah PIP bergerak di usaha kuliner, yakni sekitar 37,5\% sebagaimana dapat dilhat pada Gambar 1.
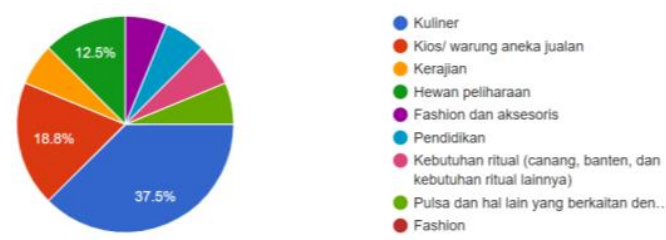

Gambar 1. Hasil Survey pada Peserta PIP Grup 19

Berikut beberapa produk yang dijual oleh peserta PIP tahap 2 yang menjual aneka kuliner serta produk kreatif lainnya (Gambar 2). Pada gambar berikut dapat dijelaskan segmen pasar utamanya adalah masyarakat Kota Denpasar, dekat lokasi usaha mereka. Dengan membidik segmen pasar lokal, memampukan mereka untuk menjual produk mereka, selain harga terjangkau juga memungkinkan dilakukannya sistem cash on delivery, sesuai dengan kebutuhan pasar saat ini. 


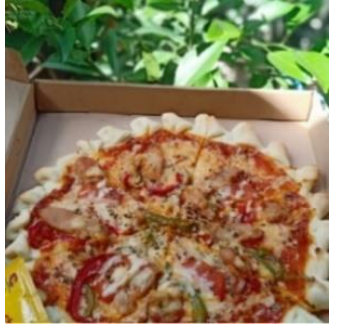

Gambar 2. Produk Umah Ratna

(Ni Luh Putu Yuli Anggreni)

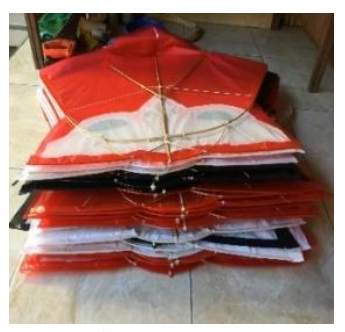

Gambar 4. Produk Kerajinan

(I Made Karnaya Adi Putra)

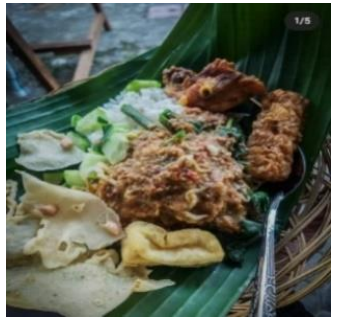

Gambar 3. Produk Nasi Pecel (Ayu Widyawati)

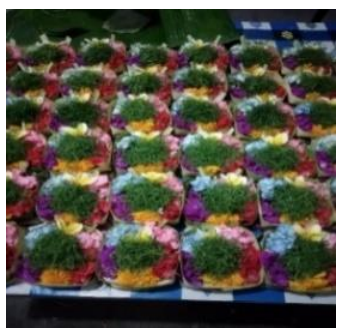

Gambar 5. Produk Swaha Bali Mesari (I Made Kareka)
Proses yang dilaksananakan lebih banyak menggunakan media sosial berupa WhatsApp sebagai sarana untuk berdiskusi, baik melalui grup maupun secara pribadi. Pernah juga bertemu dengan peserta penerima bantuan stimulus untuk melihat perkembangan usaha mereka. Diskusi melalui Googlemeet juga pernah dilakukan, namun responnya sangat sedikit, mereka mengeluhkan masalah kuota internet. Begitupula jika diberikan Youtube, sehingga Youtube tentang pemasaran produk yang diberikan kepada peserta adalah yang telah diunduh. Berikut kegiatan pedampingan yang dilaksanakan selama tiga bulan, dapat dilihat pada gambar berikut.

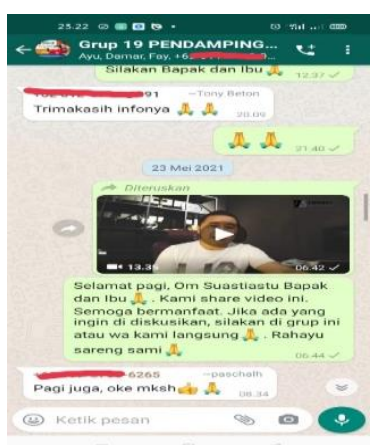

Gambar 6. Pendampingan dengan Melakukan Diskusi Melalui Grup Whatsapp

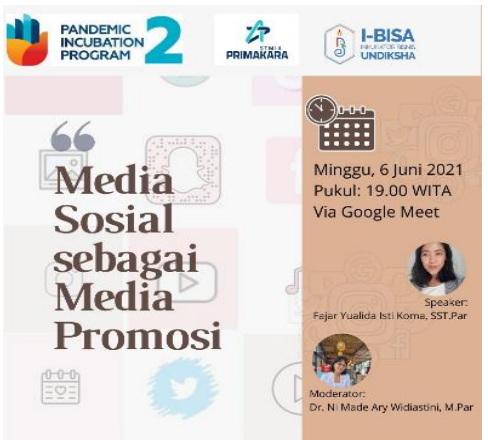

Gambar 7. Pendampingan dengan Melakukan Diskusi Virtual Melalui Googlemeet

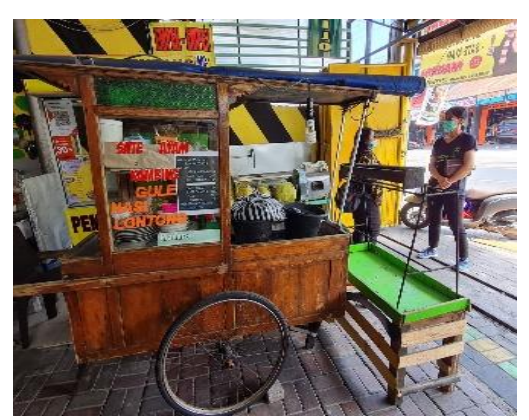

Gambar 8. Pendampingan dengan Mengunjungi Langsung Peserta Ke Tempat Jualannya

Peran usaha lokal saat ini mampu menjadi katup pengaman pemerintah, terutama di masa sulit saat ini. Sektor informal (Mustafa \& Surono, 2008), merupakan katup pengaman, dalam praktiknya sektor informal dengan segala kekurangannya mampu berperan 
sebagai penampung dan alternatif peluang kerja bagi pencari kerja, terutama mereka yang memiliki keterbatasan modal. Usaha lokal, UMKM, yang juga merupakan jenis pekerjaan di sektor informal, tentu membutuhkan pendampingan (Salomon, et al., 2019) untuk memampukan mereka tumbuh dan berkembang menjadi usaha yang bisa memberikan peluang kerja bagi masyarakat sekitar, serta berkontribusi secara ekonomi baik bagi lingkup lokal, provinsi, maupun nasional.

PIP yang dilaksanakan oleh pemerintah Kodya Denpasar merupakan program pendampingan yang diberikan kepada pemilik usaha lokal yang lulus seleksi dengan melibatkan peran perguruan tinggi melalui unit inkubator bisnisnya. Bismala et al., (2019), menjelaskan bahwa salah satu lembaga yang berperan dalam pendampingan usaha adalah inkubator bisnis, yakni melalui bentuk sinergi antara akademis, pelaku usaha dan pemerintah. Program pendampingan yang diberikan kepada 1.680 usaha yang lulus seleksi PIP tahap 2 di tahun 2021, dilakukan setelah peserta mengikuti pelatihan oleh panitia penyelenggara dan dana diberikan kepada peserta. Pendampingan dilakukan selama tiga bulan dengan melibatkan pengelola inkubator di seluruh Bali, dan dalam pelaksanaannya lebih banyak secara online, mengingat situasi penyebaran covid-19 yang masih bersifat massif. Selama pendampingan, peserta lebih banyak berdiskusi tentang pemasaran dengan menggunakan media sosial yang mereka miliki. Oleh sebab itu, selama pendampingan, peserta diberikan video tutorial tentang menggunakan media sosial dalam memasarkan produk, serta sharing session tentang media sosial sebagai media promosi yang dilaksanakan menggunakan googlemeet.

\section{Strategi Mempertahankan Usahanya yang Dilakukan oleh Penerima Pandemic Incubation Program (PIP) Tahap 2}

Teori tentang moral ekonomi petani yang dikembangkan oleh Scott (2012) bahwa setiap manusia akan berusaha mempertahankan keberlangsungan hidupnya, sehingga mereka akan melakukan berbagai bentuk perjuangan untuk bertahan. Begitupula ketika dalam kondisi sulit, persaingan usaha semakin tinggi, manusia yang pada hakikatnya adalah mahluk berpikir akan menggunakan sumber daya yang dimilikinya untuk bertahan dalam persaingan, bahkan menjadi pemenang yang memenangkan pasar. Pada kondisi ini, masyarakat juga menerapkan prinsip dahulukan selamat (safety first) yang merupakan gagasan Scott (2012) dimana seseorang akan berusaha menghindari risiko. Dalam Scott (2012) sekecil apapun risiko yang akan diterimanya, hal itu dianggap sebagai sesuatu yang membahayakan subsistensinya. Oleh sebab itu, usaha yang dikembangkan oleh peserta yang ikut program PIP2 adalah usaha yang telah ditekuninya serta sudah memiliki pasar yang jelas, sehingga bantuan yang diterima, meskipun jumlahnya kecil, mampu mendukung usaha mereka. 
Memahami persaingan yang semakin ketat dan disertai dengan tuntunan konsumen yang semakin tinggi terhadap kualitas produk dan layanan penjualan, maka sangat penting bagi usaha lokal untuk cermat untuk menentukan targetnya sebagai konsumen. Sangat penting untuk memahami karakteristik konsumen sebelum menjual produk, dengan harapan penawaran disambut baik oleh target pasar yang dibuktikan dengan dibelinya produk oleh konsumen. Berdasarkan survei yang dilakukan pada grup 19 pada program PIP tahap 2 tahun 2021, diketahui 50\% membidik pasar lokal sebagai target konsumen mereka, sebagaimana yang dapat dilihat pada gambar 9 berikut.

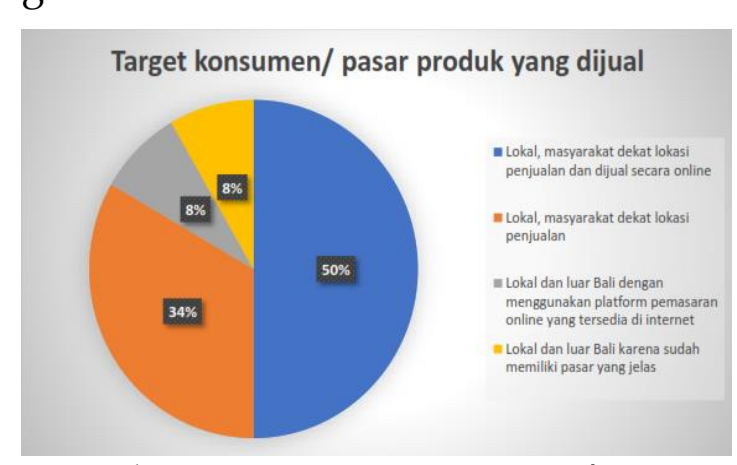

Gambar 9. Target Konsumen/ Pasar Produk Peserta PIP2

Tersedianya produk dengan jenis yang sama dalam jumlah yang banyak, tentu berdampak pada kemudahan konsumen untuk memilih produk, dan sebaliknya menjadi hal yang membutuhkan ekstra tenaga dan pikiran dalam mengembangkan produk serta cara menawarkannya.

Terlebih, perkembangan saat ini dengan hadirnya berbagai isme yang menyertai ideologi pasar, yakni meterialime, konsumerisme, hedonisme, dan lain-lain, dimana manusia sebagai konsumen tidak saja menunjukkan dirinya sebagai homo economicus tetapi juga homo consumerism (Villarino, 2011). Pada konteks ini, manusia tidak saja menggunakan pertimbangan rasional - untung rugi dalam membeli produk, tetapi lebih pada pemenuhan hasrat atau pencapaian nilai simbolik. Hal ini pun berdampak dibutuhkannya kreatifitas penjual untuk mampu menggiring konsumen yang menjadi sasarannya, memutuskan untuk melihat dan membeli produk yang ditawarkan.

Pemahaman tentang pemasaran yang baik merupakan hal penting saat ini untuk dikuasai oleh penjual dalam rangka meraih konsumen atau target pasar. Dengan memahami metode yang tepat untuk memasarkan produk, penjual akan mampu meraih konsumen dan mendapat sejumlah keuntungan. Pentingnya kemampuan memasarkan produk, dikemukakan oleh peserta penerima program stimulus PIP2 pada penjaringan kebutuhan pendampingan selain pemodalan yang dilakukan dengan penyebaran kuesiner (Google Form). Pada gambar 11, terdapat $67 \%$ dari total peserta yang mengisi form yang dibagikan membutuhkan pelatihan pemasaran. 
Pendampingan selanjutnya yang dibutuhkan selain pemodalan

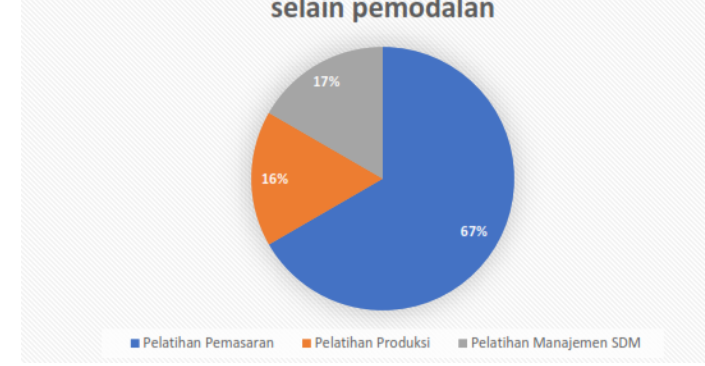

Gambar 11. Kebutuhan

Pendampingan Bagi Peserta PIP Tahap 2

Pemasaran

merupakan

kegiatan yang penting untuk dilakukan oleh setiap usaha (Kotler, 2002), dengan tujuan untuk dapat membangun hubungan yang baik kepada pihak-pihak yang terlibat dalam kegiatan penjualan produk, khususnya kepada konsumen. Pemasaran (Abiddin et al., 2017) memiliki peran yang sangat penting bagi setiap usaha dalam rangka mempertahankan dan meningkatan pendapatan. Memahami pentingnya pemasaran, sangat diharapkan pendampingan pemasaran dapat secara intensif diberikan kepada pelaku usaha, khususnya mereka yang baru merintis usaha dengan harapan usaha yang kembangkan mampu memberikan peluang kerja, dan tentunya sebagai katup pengaman pemerintah dalam mengatasi masalah pengangguran.

\section{KESIMPULAN}

Pelaksanaan PIP Tahap 2 dilaksanakan dengan melibatkan inkubator bisnis yang ada di Bali. Dalam pelaksanaannya, setiap inkubator wajib memberikan pendampingan selama tiga bulan, baik secara langsung maupun online dengan menggunakan berbagai media. Masih masifnya penyebaran virus corona yang berdampak pada diterapkannya pembatasanpembatasan, maka pendampingan online menjadi prioritas dalam memberikan masukan kepada peserta baik dalam grup maupun secara privat.

Berbagai strategi dilakukan oleh peserta penerima Pandemic Incubation Program tahap 2 dalam mempertahankan usahanya. Pemasaran secara online dan kerjasama dengan gojek atau grab pun dilakukan dalam menjual produknya. Untuk mampu meraih pasar, peserta program PIP2 menggunakan media sosial mereka, baik WhatsApp, Facebook, dan Instagram dalam memasarkan dan menjual produk mereka. Memahami pemasaran yang baik adalah faktor penting dalam meningkatkan volume penjualan, peserta program PIP2 mengharapkan adanya pendampingan pemasaran pada pasca program PIP2.

\section{DAFTAR PUSTAKA}

Abiddin, M. Z., Mas'udin, I., \& Utama, D. M. (2017). Pemilihan Strategi Pemasaran Dengan Metode SWOT Dan TOPSIS. Jurnal Teknik Industri, 18(1), 55. https://doi.org/10.22219/jtium m.vol18.no1.55-67

Adi, I. R. (2008). Intervensi Komunitas $\mathcal{E}$ Pengembangan Masyarakat Sebagai Upaya Pemberdayaan Masyarakat. PT Rajawali Press.

Barker, C. (2005). Cultural studies: teori dan praktik (Terjemahan). 
Bismala, L., Andriany, D., \& Siregar, G. (2019). Model Pendampingan Inkubator Bisnis terhadap Usaha Kecil dan Menengah (UKM) di Kota Medan. PUSKIBII (Pusat Kewirausahaan, Inovasi Dan Inkubator Bisnis ), 1(1), 1-7.

Howkins, J. (2013). The creative economy: How people make money from ideas. Penguin Group.

Kotler, P. (2002). Manajemen Pemasaran edisi milenium. (Milenium). PT. Prenhallindo.

Lestari, S. (2012). Psikologi Keluarga Penanaman Nilai dan Penanganan Konflik Dalam Keluarga. Kencana Perdana Media Grup.

Marshall, M. N. (1996). The key informant technique. Family Practice, 13(1), 92-97. https://doi.org/10.1093/fampra /13.1.92

Muslim, M. (2020). Moh . Muslim: “ PHK pada Masa Pandemi Covid19 " 358. ESENSI: Jurnal Manajemen Bisnis, 23(3), 357-370. https://www.worldometers.info /coronavirus

Mustafa, A. A., \& Surono, A. (2008). Transformasi sosial masyarakat marginal: mengukuhkan eksistensi pedagang kaki lima dalam pusaran modernitas. Institute for Supporting Programe Institution and Research Development (Inspire): Institute for Strengthening Transition Society Studies (In-Trans).

Peter, G. S. (2020). Peter garlans 2697Article Text-5957-1-10-20200925 (3). Journal OF MANAGEMENT (SME's), Vol. 12 No(2), 239-244.
Salomon, L. L. K. W., \& Sukania, I. W. (2019). Peningkatan Daya Saing. 2(2), 41-73.

Scott, J. C. (2012). Moral Ekonomi Petani: Pergolakan dan Subsistensi di Asia Tenggara. Basari H." Penerjemah. LP3ES. Terjemahan dari: The Moral Economiy of Peasant. Rebelion and Subsistence in Southeast Asia.

Suryawan, I. (2011). Teater GloBALIsme: Pariwisata, Interkoneksi Global, dan Nasib Manusia Bali di Garis Depan. Jurnal Kajian Bali, 1(1), 152-181.

Suyanto, B. (2014). Sosiologi Ekonomi: Kapitalisme dan Konsumsi di Era Masyarakat Post-Modernisme. Kencana.

Villarino, R. R. 2011. (2011). Konsumerisme. Septina Yuda Penerjemah. Bhuana Ilmu Populer. 